This is the uncorrected version of the article published subsequently as:

Nentwich, Julia C. (2006). Changing Gender: The Discursive Construction of Equal Opportunities. In: Gender, Work and Organization 13, Nr. 6, p. 499-521, DOI:10.1111/j.1468-0432.2006.00320.x.

\title{
Changing gender: The discursive construction of equal opportunities
}

\author{
Julia C. Nentwich \\ Research Institute for Organisational Psychology \\ University of St. Gallen, Switzerland \\ Varnbüelstr. 19 \\ CH-9000 St. Gallen
}

Telephone: 0041-71-224 2636

\begin{abstract}
This paper provides a discursive perspective on the dilemmas of difference and sameness feminisms and their consequences for change projects. It explores how equal opportunity officers dealing with gender issues and introducing equality legislation in practice construct the meaning of equal opportunities. The analysis of the interpretative repertoires and ideological dilemmas drawn upon in ten interviews shows the highly context-specific use of four different repertoires constructing gender equality: The sameness, difference, bandwidth and deconstructive repertoire. Interpreting the shifting between repertoires from the perspective of the ideological dilemma, new avenues for change are explored. The paper concludes that the simultaneous use of all possible theoretical perspectives might be a worthwhile objective.
\end{abstract}

Keywords: Equal opportunities, change, feminist theory, ideological dilemma, interpretative repertoires 


\section{Introduction}

"For a large class of cases - though not for all - in which we employ the word 'meaning' it can be defined thus: the meaning of a word is its use in the language." (Wittgenstein, 1958, p.

Challenging gender oppression has lain at the heart of feminist politics. Bringing about changes in gender relations in organizations has involved debates about difference and sameness, or 'difference feminism' and 'sameness feminism'; whether men and women should be treated as the same as each other, as in liberal feminism, or as different to each other, as in standpoint feminism. A key question in the debate is whether feminists should strive for women and men to be the same and foster equal opportunities, or whether men and women are inherently different and should therefore strive for the acknowledgement of these differences. Both approaches have been extensively discussed and criticized (for an overview see Evans, 1995; Phillips, 1987; Lorber, 1997). More recently, social constructionist and postmodern feminists (Hare-Mustin and Marecek, 1994; Scott, 1988; Guerrina, 2001; Knapp, 1998; Liff and Wajcmann, 1996; see also Hughes, 2002) have challenged the samenessdifference dualism. However, the debate on difference and sameness perspectives has been mainly theoretical and was slow to move out of the armchair(s) of feminist theory (Meyerson and Kolb, 2000).

My aim in this article is to move further and even beyond this theoretical debate. The paper uses discourse analysis to explore the everyday meanings and constructions of equal opportunities or gender equality ${ }^{1}$ in 10 interviews with equal opportunity officers in Switzerland. The relevance of language and seeing gender as a discursive practice has been under-researched within this context. In particular, the paper explores how professionals dealing with gender issues and equality legislation in organizations construct the meaning of equal opportunities, and looks at the consequences of their constructions. From a discursive perspective, I analyse the interpretative repertoires (Potter and Wetherell, 1987) and ideological dilemmas (Billig et al., 1988) that professional change agents in Switzerland draw upon in order to construct the subject and the objectives of their daily work. A focus on discursive practices will show the relevance and consequences of the theoretical dilemmas for the practical challenges of contemporary equality change projects. Showing how different understandings of equal opportunities are constructed in everyday talk and how they are drawn upon in a context-specific way, thereby shifting between different repertoires, will also enable a different stance on the sameness-difference dilemmas. 
The paper is organized as follows: First, I will show how change towards gender equality is conceptualised in feminist theory and will discuss the theoretical conflicts that are evolving. Second, I will introduce the discursive perspective and the methodology of the study. Third, I will present the data from professional change agents in Switzerland and the findings from the discourse analysis. Finally, I will discuss the conclusions of the study, which suggest a strategic coexistence of the disputed theoretical approaches.

\section{Feminist theory and change: the dilemmas of sameness and difference}

The objective of feminist theory is not only to explain the status quo of gender relations but to also gain knowledge on how to change them. Admittedly, these "goals are complex and diffuse”, as Anne Philips (1987) put it. The objectives require fundamental changes in several social systems such as kinship, intimate relations, sexuality, parenting, friendship, workplace relations, and the division of labour (Lorber, 1996). Feminism is clearly a much more complex and heterogeneous field than the following short overview could do justice to (e.g. Hearn, 2000). I will address some basic dilemmas, which are central for the aim of changing gender relations in the workplace, in particular the debates of sameness and difference feminism. Finally, "post-equity” approaches (Meyerson and Kolb, 2000) will be discussed as a potential means of challenging the sameness-difference dilemma.

Sameness feminism mainly draws on two liberal feminist theories (Friedan, 1982; Eisenstein, 1981; Epstein, 1988): 'liberal individualism' and 'liberal structuralism.' Both approaches aim to minimise differences between women and men observed in today's society in order to facilitate the ability of women to 'compete' on equal terms with men. Here, gender differences are not believed to be something 'natural' or 'given', but a result of sex-role socialisation. Liberal individualists argue that this socialisation process makes women less skilled at operating in a male-dominated business world and less able to 'play the game.' Attempting to solve this problem equates to training women on an individual basis so that they can acquire the skills they need to compete as equals. Therefore, whilst liberal individualists focus on 'equipping women' (Ely and Meyerson, 2000), liberal structuralists highlight the structural barriers hindering women from succeeding in male-dominated systems in organisations and society (Reskin and Roos, 1990; Kanter, 1977). Sex-differentiated structures of power and opportunity provide less access and fewer resources to women. In order to create the conditions that allow women to achieve equal opportunity, it is necessary to decrease the structural barriers. Women have to adapt to male-dominated cultures and 
masculinist norms that are taken for granted, whilst these norms go unchallenged. Within this perspective, change agents would focus on interventions to change legislation and organisational policies, which would involve designing mentoring programs, alternative career paths, flexible work arrangements, and other programs to potentially overcome discriminatory structures and oppressive cultures in order to help women achieve equality in the workplace.

However, interpreting 'equality' in the sense of 'sameness' leads to a dilemma. As it is impossible to verify the assumption that women and men really are the same, we might be in danger of treating them the same when they are, in fact, different. Treating men and women in the same way will only result in 'equality' if they really are the same. If they are not, treating them the same will be nothing but an unequal treatment (Knapp, 1998, p. 76).

The central aim of difference feminism, such as standpoint feminism (Hartsock, 1987; Harding, 1986), is to level out the hierarchical differences between women and men. In order to achieve this objective, it is important that the differences are not only acknowledged but also valued equally. Men and women are different and occupy different roles and spaces in life. They are socialised and embodied in and through multiple masculine and feminine identities. From a difference feminist perspective, one would establish diversity training and other programs to highlight gender differences and to revalue them. One would value a "woman's way" of doing things, differentiated from a "man's way", and would emphasise the special skills women bring into society, organizations and the workplace. The jeopardy in this perspective is that we might end up reinforcing gender stereotypes and therefore producing the differences. As Judith Lorber argues, there is the danger of "glorifying womanliness (which) consolidates female unity and power, but when pushed to extremes, it comes dangerously close to reviving the cult of true womanhood and the ideology of separate spheres." (1991, p. 355). From this perspective, change agents have the role of inspectors or arbitrators who check whether women have the space they need to explore their own ways of life.

Here, gender equality means treating different things differently and levelling out the hierarchical situation. However, the dilemma here is that we do not know whether we end up treating something differently that might turn out to be the same. As we do not know whether men and women are different or the same, the danger in difference feminism is of treating 
them differently despite them being the same. Again, this might lead to an unequal treatment rather than fostering equality.

The perspectives of sameness and difference feminism are at the same time interdependent and exclusive. They are interdependent insofar as sameness feminism needs a notion of difference in order to define its problems (Becker-Schmidt, 1996) and difference feminism needs a notion of sameness in the sense of 'different but equal' (Dachler, 1999) or 'equivalence' (Cornell, 1993, p. 141) in order to define its objective. Sameness feminism is impossible without a notion of difference when defining the problem, and difference feminism is impossible without a notion of sameness. While both sameness and difference feminism agree that there are hierarchical differences between women and men that need to be addressed to challenge inequity, they disagree in their basic assumptions about women and men, their visions of the future and approaches for change (Ely and Meyerson, 2000). Therefore, both perspectives are also exclusive. While difference feminism believes in unalterable differences between women and men, sameness feminism states that they are the same. While difference feminism would challenge the hierarchical relation of women and men, sameness feminism aims at abolishing the differences altogether. These assumptions are contradictory, as they force feminists and practitioners to make a choice, assuming that only one approach can be true at one point in time (Scott, 1988, p. 43). These dilemmas of sameness and difference feminism have been discussed widely, and post-equity approaches have been suggested as a possible way out (Scott, 1988; Lorber, 1994; Knapp, 1998).

This third perspective - the "post-equity" (Meyerson and Kolb, 2000) or deconstructive approach (Knapp, 1998) - is put forward by Scott (1988), Knapp (1998), Ely (2000), and Guerrina (2001), and draws on poststructuralism (Butler, 1993, 1990) and social constructionist or 'doing gender' approaches (West and Zimmerman, 1987). Here, gender is seen as organised through social practices (Gherardi, 1995, 1994). For instance, organisations are interpreted as gendered and patterned through discourse. Gender is the organising principle that shapes social structure, identities, power and knowledge, and is no longer something individuals 'have.' It is the social and discursive practices that construct norms with white, heterosexual, class-privileged men as the 'neutral and objective' standard. The focus here is not on individual men and women, or on organizational structures, but rather on the social practices constructing gender. The focus for initiating change lies within changing these practices: Once we identify the particular ways in which certain organisational, 
discursive or social practices produce gender inequities, they may become potential targets for experimentation and change.

The 'post-equity' perspective leads a path out of the sameness-difference dilemma described above because it enables the challenge of the basic assumptions of the gender system in today's Western industrialized countries: the dichotomy of women and men (cf. Oseen, 1997; Lorber, 1996; Hagemann-White, 1989; Jay, 1989). Conceptualising gender as a social practice, it takes into account that both difference and sameness feminism have been developed within specific social, economic and political structures and are based on the assumptions of the gender system, for instance the gendered divisions of labour (Guerrina, 2001, p. 34). Challenging this dichotomy challenges or deconstructs gender as a concept (Hughes, 2002, p. 18; Knapp, 1998; Baxter and Hughes, 2004; Lorber, 1996, 2000) and highlights the importance of context for making sense (Scott, 1988), but is not an easy endeavour (see Hearn, 2000; Acker, 2000; Meyerson and Kolb, 2000).

However, research about change and intervention projects from a post-equity perspective is still rare (cf. Hearn, 2000). The few studies that do exist mainly focus on the issue of applying these perspectives to organizational change projects (Liff and Cameron, 1997; Rapoport et al., 2002; Rao et al., 1999; Meyerson and Kolb, 2000; Ely and Meyerson, 2000). The central emphasis is on the processes constructing gender in a certain context. Regarding the contradictions between sameness-difference discussed above, these studies suggest ignoring them altogether and utilizing all approaches, if suitable, within a certain context. However, these are interesting new approaches, but they do not solve the sameness-difference dilemma. Although gender is treated as a social construction, the concepts of gender equality seem to be pre-given entities and are treated as pre-given frames of analysis. Change agents are thought to be free to choose a perspective for a certain problem in a specific situation. What has been neglected so far is the question of how the meaning of gender equality is constructed in the context of a change project, and in particular for this paper in several organizational contexts in Switzerland. What I am suggesting here is a 'discursive turn' (cf. Burman and Parker, 1993) in the debate about gender equality, focusing on the question of how 'gender equality' is constructed in talk and text. In the following section, I will show how this perspective enables a new way of dealing with the theoretical tensions and dilemmas and therefore shows a possible new avenue for the major objective of changing gender relations.

\section{The study: Equal opportunities as discursive constructions}


Although language is a central point of analysis in social constructionist research on gender (cf. Weatherall, 2002; Speer, 2005), the discursive practices constructing the meaning of equal opportunities have been neglected. However, focusing on dilemmas as in sameness and difference feminism, discourse analytic approaches might be particularly helpful. Research in the field of 'discursive psychology' (Edley, 2001; Speer, 2005; Wetherell, 1998; Edwards and Potter, 1992; Billig, 1996; Potter and Wetherell, 1987) has shown abundantly that people engaging in everyday talk do not merely utter singular attitudes but use complex and often even contradictory accounts.

This contradictory nature of everyday talk has also been found in research on the discursive construction of equal opportunities. For instance, Wetherell, Stiven and Potter (1987) have shown that in everyday talk, there is not only one meaning of equal opportunities, but rather many meanings. They identified two versions or 'interpretative repertoires' (Gilbert and Mulkay, 1984) of equal opportunities: a belief in "equal opportunities" as an abstract concept and "practical considerations" (Wetherell et al., 1987, p. 61-62) contradicting the realization of equal opportunities in given organizational situations. Interestingly, in their study, both versions co-occurred in the same text and were uttered by the same speaker while the contradiction remained unnoticed. Meriläinen (2001) identified 'sameness' and 'difference' as the two discourses upon which two bank managers draw when constructing their situation as working mothers. Riley (2002) highlights how the work context is constructed as genderneutral, and an abstract principle of individualism is favoured in professional men's accounts on discrimination and equality.

These three studies on the discursive construction of gender equality show that the everyday rhetoric always contains what Billig and colleagues (1988; cf. Benschop et al., 2001) have called an ideological dilemma. Here, ideologies are always ambiguous, and common sense is contradictory in that it contains opposing themes that have to be negotiated in a situation. Billig and colleagues conclude that every construction of reality has to draw upon different and disagreeing repertoires in order to make sense, and it is precisely these dilemmas that make ideologies strong and unquestioned. Interestingly, in the lived ideology of everyday talk, these dilemmas are not forced in the criticized 'either-or' way of deciding which one is more 'true' than the other.

The discursive perspective, which focuses on the everyday practices of meaning-making, provides a new perspective on the contradictions between sameness and difference in feminist 
theory. Usually, dilemmas are solved through favouring one side of the dilemma over the other, valuing one concept as more important or true than the other. Such an enforcement of an 'either-or' decision between two positions inhibits the possibilities of agency and therefore change. It is this 'either-or' which is no longer necessary, as a discursive perspective goes beyond such a binary thinking because both repertoires of sameness and difference are drawn upon in everyday talk. Both sides are equally valued, and neither is valued as 'higher' or 'truer' than the other, thus enabling other choices in terms of agency. In the case of gender equality:

"the concept of ideological dilemma enables us to deal with conflicting notions, like the notions about the nature of the individual ('we are all different'), equality ('we are all the same'), the nature of the social group (in terms of categories of 'men' and 'women'), and fairness ('equal treatment for equal cases')." (Benschop et al., 2001, p. 17)

Interpreting the tension between sameness and difference as an ideological dilemma, one would not only expect several meanings to be available to draw upon and shift between, but also focus on the consequences of a certain meaning in a specific context. The concepts become fluid, meaning that they can be drawn upon in order to construct a specific reality and can be shifted between. Leaving behind the idea of opposing approaches, it becomes possible to see all three feminist perspectives as different possibilities for change and change agency. In other words, all available discourses can be used simultaneously and are not exclusive (Nentwich, 2004). Different perspectives can stand side by side, all of them applicable and valid in a certain context. Analysing the discourses or interpretative repertoires drawn upon will shed light not only on the interpretative repertoires in use, but also on their specific contexts and their specific consequences with regard to different possibilities of change.

Having outlined the perspective of equal opportunities as a discursive practice, I will now turn to the analysis of the interpretative repertoires and theoretical discourses upon which change agents in Switzerland draw in order to construct their versions of gender equality. Showing how they shift from one repertoire to another, I highlight the construction of gender equality in the change process and the functioning of the ideological dilemmas involved. Three research questions are addressed:

(1) How do change agents discursively construct the meaning of equal opportunity? 
(2) How are their constructions a product of the debates on sameness, differences or postequity approaches within feminist theory?

(3) What are the consequences of these constructions for the change project(s) and for change agency?

I conducted 10 problem-centred interviews (Witzel, 2000) with change agents in Switzerland. In Switzerland (and also Germany and Austria), change agency for equal opportunity projects has been assigned to specific persons or jobs. In the 1990s, it became institutionalised in the so-called 'equal opportunity offices.' Here, 'equal opportunity officers' ('Gleichstellungsbeauftragte' in German) took over the objectives of the women's movement and started to foster a change process within the established structures (Eidgenössische Kommission für Frauenfragen, 1995, 1998; Ballmer-Cao, 2000). Given its roots in the women's movement, the position is still dominated by women. Although important changes have occurred in the past few decades and many Swiss people consider gender equality to be 'politically correct' and a necessity in modern society, others still devalue it or fail to see it as important or urgent. Fostering equal opportunities is still associated with the struggle for women's rights and therefore with an unwelcome opposition to men. Therefore, the equal opportunity officers often find themselves in a paradoxical situation - they are hired to foster equal opportunities and at the same time are neither valued nor taken seriously. Equal opportunity officers today face considerable pressure; in a context of financial cutbacks, their offices are continuously being re-evaluated and accused of being merely unnecessary expenses.

My sample of ten interview partners mirrors the current situation in the Swiss equal opportunity movement and is very heterogeneous. For example, not all Swiss cantons have an official equality representative and there are no regulations stipulating how the national law regarding gender equality ${ }^{2}$ is to be implemented in a given firm. While conducting ${ }^{3}$ the study, I tried to talk to all of the official equal opportunity officers in the four cantons of Eastern Switzerland. ${ }^{4}$ Three of my interview partners were equal opportunity officers in canton governments, two worked in the same public organization, and two in firms. ${ }^{5}$ The perspective at the two firms was complemented by interviews with two women in management positions from two other companies. Although they do not have official job descriptions as equal opportunity officers, these women's co-workers associate them with equality opportunity issues. Additionally, I conducted one interview with the president of a women's organization that is taking over the responsibilities and tasks of a canton-level equal opportunity office. 
The educational background of these professional women is equally diverse: Six are academics with degrees in psychology, history and engineering, while two have a background in social work and two in business administration and management. This heterogeneous background is the symptom of the lack of institutionalisation of this career. However, despite their heterogeneity, all are hired to foster the same objective: implementing change towards gender equality.

\begin{tabular}{|l|l|l|}
\hline Interview No. & Job Title & Institution \\
\hline 1 & Equal opportunity officer & Public Organization A \\
\hline 2 & Equal opportunity officer & Canton Government A \\
\hline 3 & Equal opportunity officer & Canton Government B \\
\hline 4 & Equal opportunity officer & Public Organization A \\
\hline 5 & Equal opportunity officer & Canton Government C \\
\hline 6 & President & Women's Organization \\
\hline 7 & Equal opportunity officer & Firm A (Research institution) \\
\hline 9 & Equal opportunity officer & Firm B (Industry) \\
\hline 10 & $\begin{array}{l}\text { Associated with equal opportunity } \\
\text { issues }\end{array}$ & Firm C (Industry) \\
\hline & Associated with equal opportunity & Firm D (Service Industry) \\
\hline
\end{tabular}

Table 1: The interviewees' institutional background

In order to investigate how the theoretical discourses become relevant in the interviewees' accounts and narratives about their daily practices, I conducted 10 problem-centred interviews (Witzel, 2000). They followed a flexible interview guideline with questions focusing on the women's daily work, their definition of the current problems regarding equal opportunities, their personal vision for the future, and their preferred approach to change. For instance, I asked questions about their own and their employer's motivation and objectives for the job of an equal opportunity officer, about the vision of a future in which gender equality would have become reality, the changes one would have to expect in the company or the organization, and all the separate small steps necessary to develop this vision. I also asked about critical incidents (Chell, 1998), both positive and negative, which they had experienced on the job and asked them to evaluate them. Each individual interview lasted between 45 and 90 minutes. 
Analysing how the change agents discursively construct equal opportunities, the interpretative repertoires drawn upon in talk and how their constructions are linked to the debates on sameness, differences or post-equity approaches within feminist theory and what consequences their constructions have for the interventions they are planning, I conducted discourse analysis (Potter and Wetherell, 1987; Wood and Kroger, 2000; Gill, 2000; Antaki et al., 2003). I was interested in the themes and theories the interviewed women use to formulate their view on gender equality and their daily business within the field in order to analyse their basic assumptions and the consequences for change and change agency.

\section{The discursive construction of equal opportunities}

Analysing the interviews with Swiss equality representatives, the four analytical levels 'problem definition', 'approach to change', 'vision for the future' and 'definition of gender' described by Ely and Meyerson (2000) turned out to be important contexts for the variety of interpretative repertoires. Talking about gender equality, the interviewees shifted between the discourses of 'difference', 'sameness' and 'post-equity' feminism (deconstruction) and also used a 'bandwidth' repertoire. While the 'sameness' discourse was exclusively drawn upon when talking about the problem definition, the approach to change and the vision for the future, the situation became more ambiguous when looking at the definition of gender. Here, a total of three interpretative repertoires - 'difference', 'bandwidth' and 'deconstruction' - are in use, while the 'sameness repertoire' was completely ignored in this context. I will present the results structured according to the four analytical levels of gender equality (Ely and Meyerson, 2000), starting with the problem definition, followed by the approach to change, the vision for the future and the underlying definition of gender.

\section{The problem definition}

When the interviewees spoke about equal opportunities and the difficulties inherent in the Swiss situation, one major theme that emerged was the perceived problems in today's society. The main problem for Swiss equal opportunity officers seems to be the differences between women and men.

In general, men work 100\%, have a nice woman at home and a couple of cute little children. And they consider this to be how it should be and believe that a 'real woman' ... obviously does not have the desire to do anything else than be taken care of and look after the children and be responsible for a nice atmosphere. This is totally clear to them. And the women who do not want to be like this, they are all crazy about a career. (Interview 8, equal opportunity officer, industry) 
Explaining these perceived differences between men and women, the interviewees did not draw on difference feminism, but rather on accounts provided by sameness feminism: structural and individual characteristics. Focusing on differences in structures, the discussion in the interviews spotlighted the segregation of work in firms as well as in society in general. In firms, women and men are portrayed as working in different places, having different jobs and different possibilities. In Swiss society, women are described as still responsible for the family and the 'soft factors' of life such as taking care of children.

Besides these structural differences, the interviewees mentioned individual differences. Men and women are perceived as having different points of view; they do things differently and have different attitudes. They are also thought to differ in their talents and interests; e.g. men think more rationally and are more competitive than women. Here, it is mostly unclear whether these perceived differences are explained through socialization or seen as natural differences, therefore leaving it open whether the perspective constitutes mainly sameness or difference feminism. In order to explain the low proportion of women in leadership positions, those using the liberal individualist argument pointed out that women tend to understate their competence. In contrast, they think men overrate their own abilities.

Thus, the interviewees identify the main problem of today's situation as lying in the differences between women and men; either in terms of structure, gender roles or individual characteristics. However, to account for the perceived problems, they draw mainly on the sameness perspectives. It is mostly differences that can be explained by socialisation and societal structures and therefore provide rationales for the work of an equal opportunity officer: The major objective of their daily work is to moderate the described differences. How they translate this objective into action is the topic of the next section.

\section{The approach to change}

Talking about the next steps needed in the change process in Swiss society, the women interviewed all agreed that the first steps have already been taken in recent years. Now, they say, it is important to keep this process going. This means getting involved in everyday work, and stating clearly what aspect should change next. "Getting into details" also means that "now is not the time for provocation" (Interview 1, equal opportunity officer, public organization A) as it was in the beginning of the women's movement. The aim now is to transform society step by step. This implies hard daily work to continue the slow-moving process, in contrast to the radical actions in 1991 when many women in Switzerland went on strike. One interviewee (Interview 10, woman associated with equal opportunity issues, 
service industry) says that she sees no place for the adherents of women's liberation or 'women's libbers' fighting for women's rights in Switzerland, drawing on the difference discourse of the 1970's; what society needs today are 'equality professionals' who have been trained in being diplomatic. These women describe the movement as having changed from spontaneous political actions to a professionally designed change process.

This change in argument used to describe the change process in general explains why the necessary next steps are very detailed suggestions and individual solutions. As was the case for the problem definition, the arguments they used here draw on the structural as well as on individualistic perspectives. The main theoretical discourse drawn upon is sameness feminism. One urgent point raised was the requirement of support for families such as nursery schools and kindergartens, a school system guaranteeing childcare from 8 am to 5 pm every day, parental leave programs, and maternity grants. The interviewees also commented on the structures in companies, which must become more attractive to women by increasing opportunities for part-time work and moderating the division of work between the genders. The mainly liberal individualistic perspectives used here differ in an interesting way from the accounts described in theory. It is no longer the individual woman who has to change in order to adjust to the male structures. Now, it is said to be the men's turn to change: Women have taken the first step and now men have to follow. Men have to give up their claim to power and to assume responsibilities in the family.

The men, the men! That men, that the men start daring to commit themselves to the issue, this is the next step towards gender equality! (Interview 1), equal opportunity officer, public organization A)

This would mean "investing intellectually on the men's side because otherwise nothing will happen at all" (Interview 1, equal opportunity officer, public organization A). The key idea here is to find ways to alert men to the issue, perhaps by offering incentives and role models to help to change their perspective. The picture painted here is of two traditional worlds in one; one for women and another for men. But it is no longer the women who are asked to travel from the women's world to the men's world and bear the double burden of both. Now, the men are asked to start making the same journey in the other direction: travelling from the traditional male world of business and labour to the former female world of care provision within the family. 
Talking about the problem definition and the approach to change, the main approaches the women interviewed articulated are decreasing differences between men and women and increasing opportunities for both. The vision for the future seems to be the other side of the coin of the problem definition - a vision of gender equality in which today's differences will have disappeared.

\section{The vision for the future}

When discussing the future, the interviewees again perceived the sameness perspective as the major source of inspiration. Asked to look ahead 20 years, the equality professionals described a world with as many women as men in government and leadership positions. Where today, male CEOs are the norm, in the future there will be women, and in the rest of the organisation there will also be as many women as men in various jobs and hierarchical levels. Women will have started to work in traditionally male fields and men will have started to take over traditional women's jobs; in the future, typical female jobs and male jobs will no longer exist because both men and women will have developed similar interests and skills.

My personal vision would be first that there are no longer any equality representatives. They will not be needed any longer... and gender relations in general will have made the step into a new era. However, sensitivity to the topic will have increased, stereotypes will be reduced, and being human, being a woman or being a man will be on the same level. Socialised differences would be equalised. Of course, that would be paradise! (Interview 1, equal opportunity officer, public organization A)

The women also envisioned a time when gender is no longer relevant, when it will merely be important to have the right person with the most appropriate set of skills in the position. In this scenario, gender will no longer be the criterion for selecting people for jobs. But this vision will not only apply to paid work; the unpaid work sector will also be distributed differently. Men and women will be responsible for childcare, housekeeping and the care of the elderly and disabled. In this future, it will be possible to choose a career taking care of children or to establish oneself in a demanding corporate job, or to combine both job and family.

The basic structural requirements for the new world described in the interviewees' visions are that women will not only be financially independent from their partners but will also have the same amount and quality of skills and education as men. High-quality childcare will be offered, and used widely. Companies will have become family-friendly. One important step in 
this process is a change in the understanding of part-time work, which will become possible in all jobs, for both men and women, and will be taken for granted more than it is today. Both mothers and fathers will have the possibility of parental leave programs. Private home and public work roles will no longer be incompatible dichotomies, but will be more integrated and balanced. Children will be seen as important to the development of a society rather than obstacles to a career or other goals.

In the visions described here, differences between women and men have become less obvious or have even disappeared altogether. In this vision, structures as well as individuals have changed and the differences between women and men seem to have blurred. Thus, the understanding of gender equality here reflects no differences between the genders, or else gender is no longer a relevant category in the envisioned future. While the sameness perspective dominates not only the problem definition and the vision for the future but also the approaches to change, the situation becomes more complex when investigating the definition of gender. As I will show below, there are three different interpretative repertoires when talking about gender in the context of equal opportunities.

\section{The definition of gender}

Talking explicitly about gender and gender differences, the ten women interviewed see a more complex situation compared to the visionary world described above. As they talked about the perceived problems, the approach to change and their visions, the arguments focused on moderating differences between women and men, the general idea being that they will become equal in the sense of sameness. This idea changed when they talked about the definition of gender. In total, three different interpretative repertoires were used by the interviewed women, which I call 'difference,' 'bandwidth' and 'deconstruction.' The three repertoires offer different concepts, terms and metaphors to characterize different understandings of gender.

\section{The difference repertoire}

One repertoire used in the interviews when talking about gender is the 'difference repertoire.' It focuses on perceived differences between women and men: "Well, despite equality we will never be the same!' (Interview 3, equal opportunity officer, canton government B). Even if the goal of equality is achieved in 20 years, women and men will still be different in this repertoire. And these differences in attitudes, abilities and interests are mainly rooted in biology. The basic difference between women and men stems from the fact that even in 20 
years' time, it still will be women who give birth to children. On the other hand, as these women stress, being able to have children does not automatically mean that women must be responsible for taking care of them. Despite biological differences, it should be possible to share work and family roles equally. Biology plays a major role in this repertoire but it is not seen as the basic explanation for the gender system currently in place in Swiss society.

There will probably always be women who somehow, if they have children, have the feeling that they want to be the ones mainly taking care of the children. (Interview 3, equal opportunity officer, canton government B)

The main topic here is not biology but gender difference. Differences should not be overlooked; they should be recognised, appreciated and, indeed, cherished. The impossibility of sameness is seen as valuable and important. This stance entails a change process towards a society that achieves equal rights and equal opportunities, but not equality in the sense of sameness: "Equal opportunities and equal rights, but I don't want everybody to be the same and no levelling down of differences" (Interview 7, equal opportunity officer, research institution). From this perspective, the vision of the future is that women and men are allowed to be different but find new ways to live and work together. This living together is made possible by the idea of equal opportunities for both genders and a model of well balanced, evenly matched partners in a relationship. In this repertoire, the basic assumption draws on the difference perspective: gender is based on biological difference and this difference is important and cannot be changed. What is subject to change here is the hierarchy between the genders, but not difference.

\section{The bandwidth repertoire}

A second interpretative repertoire used in the interviews when talking about gender is the 'bandwidth repertoire.' In this repertoire, the overall topic is a bandwidth or a "wider spectrum" of possibilities for everyone.

There will be a wider spectrum of being male and a wider spectrum of being female. (Interview 1, equal opportunity officer, public organization A)

As in the difference repertoire, respondents see biological differences, but here they also strongly emphasise the social construction of gender roles. The differences between women and men are thought to have a biological basis or sex and a supplement, gender, which can be explained by the socialisation process. Some biological differences are said to exist before the socialisation process but other differences are subject to change. In this repertoire, the basic issue is changing these socially constructed gender roles. Doing so would mean neutralising 
the differences between the genders. Neutralisation in this context means opening up the possibilities of being female and being male, but not eliminating all differences. This would mean, for example, that differences in the biographies of women and men as we know them today will grow more similar until we can hardly tell them apart. But women and men will still differ in their biological characteristics. At this point, it is not clear how these remaining differences will be acted out and how they will be recognised in the future.

The basic argument here is the "bandwidth of differences." The assumption is that if we open up our perceptions to see more differences between human beings, then only the biological sex differences will exist; there will no longer be just one way of being a woman or a man. There will be many possibilities for designing biographies and fostering all potential and abilities. The objective is to make the sex differences less exclusive and to create a society with diverse differences between both women and men, and within the categories of women and of men. Or, as one interview partner put it, "There are also differences between women and women and between men and men and between women and men and variety! When we recognise this, we will get to the point where we have variety!” (Interview 4, equal opportunity officer, public organization A).

According to this view, even if the women are still taking primary responsibility for the children, it will also be taken for granted that men can work as caregivers too. From this perspective, mothers are responsible because of biology; fathers will increase their involvement because they want to. The basic assumption in this interpretative repertoire is that gender is based on a biological difference. But despite this difference, gender has to be changed in order to create variety. Here, it is the hierarchy between the women and men and the binary differences in today's gender system that have to be eliminated. Both changes are thought to be possible through multiplying differences. Focusing on differences between people in general will resolve the binary aspect of the differences and therefore the hierarchy between women and men as well.

\section{The deconstructive repertoire}

In the third interpretative repertoire, the "paradise" or the described vision would be a reality in which all hierarchical differences are eliminated between men, women, and human beings.

Being human, being female, being male would be on the same level. This would be paradise when everything would be equalised. (Interview 1, equal opportunity officer, public organization A) 
This would mean that men and women have adjusted to each other and all differences in hierarchy have vanished. But not only the hierarchy would be gone; the gender system itself would also have to change its basic assumptions. This implies cutting the historically grown roots of today's gender system in order to provide the space to invent something new. This could lead to a new definition of the gender system in a new context and interpretative framework and would mean "that gender relations have stepped into a new era" (Interview 1, equal opportunity officer, public organization A).

In this repertoire, the primary objective is to increase the options for everyone. A new definition of the gender system would therefore not automatically imply that all differences have vanished but would open up a range of possibilities: "Simply that one has more options. ... And it will be okay if someone wants to live according to a traditional model. If someone is content with that" (Interview 2, equal opportunity officer, canton government A). Someone eager to live a traditional role model would be free to choose this possibility, as another person would be free to choose something else. In this perspective, there would be more possibilities of and opportunities for masculinity and femininity, for 'doing' men, women or human beings.

The basic assumption in the deconstructive repertoire, basically drawing on the post-equity perspective, is that gender is a social construction and therefore change in every direction is imaginable and possible. The key is to eliminate the hierarchy between the genders, but differences in general are also negotiable and can be the objects of change. The belief is that if the basic assumption of differences between women and men is not challenged, the hierarchy will remain in place.

\section{Equal opportunities as ideological dilemmas}

With regard to change, the analysis reveals two challenges. First, the argumentation defining gender equality is incoherent across the four different levels of gender equality as defined by Ely and Meyerson (2000). Talking about the problem definition, the approach to change and the vision for the future, the answer seemed to be clear: Gender equality would mean a world in which women and men are the same, a world in which today's differences have been moderated or have disappeared completely. The arguments used by the equal opportunity officers draw primarily on the liberal individualist and the liberal structuralist perspectives. 'Equality' was used here in the sense of sameness, and differences played a role when talking about today's problems and inequalities. This changed, however, as the interviewees discussed the definition of gender. Here, three more perspectives on gender become apparent: 
Cherishing differences, accepting a bandwidth of differences, and deconstructing differences. Interestingly, bringing a specific argument into play depended on the context of the argumentation in the interview.

Second, the discursive patterns mirror the dilemmas in feminist theory. Arguing for sameness when talking about the vision for the future and differences when talking about what gender is or today's problems reveals an ideological dilemma of everyday talk (Billig et al., 1988). Thus, the analysis has shown that sameness and difference feminism are not only interdependent and exclusive in theory, but also in everyday talk. All interviewees used an account of difference to define today's problems and a notion of sameness when defining the objective of the change process. The more they focused on the vision for the future, the more they argued for an objective of sameness. Up to this point, the argumentation seemed to be logical: today's differences have to be changed in order to achieve equality in the future. But the repertoires are also highly context-specific and therefore exclusive. For instance, the sameness repertoire was exclusively used when defining what the problem is all about, how to change it and the vision for the future. But when talking about their beliefs concerning what gender is, the repertoires became more exclusive. Depending on the context, the three interpretative repertoires were utilized in order to moderate the objective of equality or a specific measurement applied. For instance, arguing for diminishing differences in the future, interview partner 3 (equal opportunity officer, canton government B) does not want to eliminate them completely as she has a strong belief in women and men being different. For interview partner 1 , it is the other way round (equal opportunity officer, public organization A). She would love to support a deconstructionist movement and a future without any gendered categories. However, she does not see how the concept can be translated into action in a concrete change project and therefore draws upon sameness feminism in order to describe approaches for change. Shifting from one repertoire to another could therefore be interpreted as a strategy of dealing with the tensions inherited from feminist theory. And, as theory suggests (Billig et al., 1988), as long as one repertoire is exclusively used in one context, it serves to construct a stable version of reality.

\section{Consequences for changing gender}

Looking at these contradictions in the equal opportunity officers' accounts from the perspective of the ideological dilemma, it is important to acknowledge that different ideologies exist and are used simultaneously. What other studies have been suggesting (Liff and Cameron, 1997; Rapoport et al., 2002; Rao et al., 1999; Meyerson and Kolb, 2000; Ely 
and Meyerson, 2000), namely the strategic and simultaneous use of all possible theoretical approaches, is in fact already an everyday practice. Following this line of argument, it might be interesting to see what would happen if different repertoires were drawn upon in a certain context. For instance, is it possible to talk about the problem definition drawing upon a sameness perspective? With regard to change, it might be worthwhile to try out other strategies than those of liberal feminism. This could lead to a strategy that sees all available discourses as equal, not favouring one over the other. In this sense, creating new strategies for change would mean trying out and playing around with many possible understandings and perspectives instead of favouring one side over the other and forcing a decision. 'Playing around' would mean systematically analysing the interpretative repertoires used, the discourses drawn upon, the assumptions made, and the identities constructed in order to investigate the possible consequences of each one. Knowing the consequences in a certain context would provide a basis for making strategic decisions in the process of change towards equality.

Exploring the consequences of every repertoire used in the interviews - both theoretical and argumentative - would lead to a richer and more detailed patchwork of perspectives on what gender equality could mean from a post-equity perspective. This would not only stimulate more critical reflection; it would also offer potential solutions to the question of how a future change process could be designed in a specific context in which every argument can be viewed as one possible solution (Dachler and Rüegg-Stürm, 2000, p. 17). And, following de Shazer et al. (2001, p. 175), it would also be important to investigate the accounts not used in a specific argumentation, as they might be the basis for constructing new solutions. As we discussed gender equality in the interviews, the interviewees did not use every possible argument to construct a solution and a possible action in the change process. For example, the interviewees considered the deconstructive repertoire, leading to a world with moderated differences, to be a visionary, more theoretical approach and not really applicable to everyday actions. Thus, the deconstructive repertoire seems to be available to those talking about visions, but does not seem accessible when talking about the definition of gender or change. These limits on accessibility make it harder to use all of the possible approaches in a strategic way in order to generate multiple solutions for the problem.

Given these limitations, the "safe spaces" that Collins \{, 1991 \#2009\} describes would provide room to explore new practices. There, it would be possible to facilitate reflection, deconstruction and reconstruction, and allow both theorists and practitioners to 'play around' 
with the positions, arguments and consequences of different interpretative repertoires without reinforcing the need to focus on any one best way or one solution to the situation. Such an environment could provide the framework in which to start thinking about and imagining a gender-equal society, although we cannot know how it would look: "we do not know what the values, individual personality traits, and culture of a nonhierarchical society would be like, and we have great difficulty in imagining it. But to imagine it we must think that it is possible. And it is possible. Practices produce values; other practices produce other values" (Delphy, 1993, p. 8). Doing so would imply stepping beyond the theoretical boundaries, as well as those in everyday thinking. And, as the notion of the ideological dilemma has shown, using all possible perspectives and interpretative repertoires in a strategic manner could be a fruitful way in which to produce new practices.

\section{Acknowledgements}

An earlier version of this article was presented in 2002 at the $18^{\text {th }}$ EGOS Colloquium in Barcelona, Spain. The article has benefited a great deal from my discussions with Elisabeth Kelan. I would like to thank her, Alison Linstead and an anonymous reviewer for their very valuable comments and patience in developing this paper. 


\section{Literature}

Acker, J. (2000) Gendered contradictions in organizational equity projects. Organization, 7,4, 625-632.

Antaki, C., Billig, M., Edwards, D. and Potter, J. (2003) Discourse analysis means doing analysis: A critique of six analytic shortcomings. Discourse Analysis Online, 1,1. Online at http://www.shu.ac.uk/daol/articles/v1/n1/a1/antaki2002002-paper.html.

Ballmer-Cao, T.-H. (2000) Sozialer Wandel und Geschlecht. Zur Gleichstellungsfrage in der Schweiz. Verlag Haupt: Bern.

Baxter, L. and Hughes, C. (2004) Tongue sandwiches and bagel days: Sex, food and mindbody dualism. Gender, Work and Organization, 11,4, 363-380.

Becker-Schmidt, R. (1996) Einheit - Zweiheit - Vielheit. Identitätslogische Implikationen in feministischen Emanzipationskonzepten. Zeitschrift für Frauenforschung, 14,1 \& 2, 5 19.

Benschop, Y., Halsema, L. and Schreurs, P. (2001) The division of labour and inequalities between the sexes: An ideological dilemma. Gender, Work and Organization, 8,1, 118.

Billig, M. (1996) Arguing and thinking. A rhetorical approach to social psychology. Cambridge University Press: Cambridge.

Billig, M., Condor, S., Edwards, D., Crane, M., Middleton, D. and Radley, A. (1988) Ideological dilemmas: A social psychology. Sage: London.

Burman, E. and Parker, I. (1993) Discourse analytic research: Repertoires and readings of texts in action. Routledge: London.

Butler, J. (1990) Gender trouble. Feminism and the subversion of identity. Routledge: New York.

Butler, J. (1993) Bodies that matter. On the discursive limits of 'sex.' Routledge: New York.

Chell, E. (1998) Critical incident technique. In Symon, G. and Cassell, C. Qualitative methods and analysis in organizational research: a practical guide, pp. 51-72. Sage: Thousand Oaks.

Collins, P. H. (1991) Black feminist thought: knowledge, consciousness, and the politics of empowerment. Routledge: New York.

Cornell, D. (1993) Transformations. Routledge: New York.

Dachler, H. P. (1999) Alternatives to individual conceptions of global leadership. Dealing with multiple perspectives. Advances in Global Leadership, 1, 75-98. 
Dachler, H. P. and Rüegg-Stürm, J. (2000) Beyond mere management - critical challenges in fundamental organizational change processes from a systemic-relationalconstructionist perspective. Working Paper IFB, University of St. Gallen.

Delphy, C. (1993) Rethinking sex and gender. Women's Studies Int. Forum, 16,1, 1-9.

Edley, N. (2001) Analysing masculinity: interpretative repertoires, ideological dilemmas and subject positions. In Wetherell, M. Discourse as data: a guide for analysis, pp. 189228. Sage: London.

Edwards, D. and Potter, J. (1992) Discursive psychology. Sage: London.

Eidgenössische Kommission für Frauenfragen (1995) Viel erreicht - wenig verändert? Zur Situation der Frauen in der Schweiz. Bern.

Eidgenössische Kommission für Frauenfragen (1998) Frauen Macht Geschichte. Online at: www.frauenkommission.ch/geschichte_d.htm. Bern.

Eisenstein, Z. (1981) The radical future of liberal feminism. Longman: New York.

Ely, R. J. and Meyerson, D. E. (2000) Theories of gender in organizations: A new approach to organizational analysis and change. Research in Organizational Behaviour, 22, 103151.

Epstein, C. F. (1988) Deceptive distinctions: Sex, gender and the social order. Yale University Press: New Haven.

Evans, J. (1995) Feminist theory today: An introduction to second-wave feminism. Sage: London.

Friedan, B. (1982) The feminine mystique. Penguin: Harmondsworth.

Gherardi, S. (1994) The gender we think, the gender we do in our everyday organizational lives. Human Relations, 47,6, 591-610.

Gherardi, S. (1995) Gender, symbolism and organizational cultures. Sage: London.

Gilbert, G. N. and Mulkay, M. (1984) Opening Pandora's Box: a sociological analysis of scientist's discourses. Cambridge University Press: Cambridge.

Gill, R. (2000) Discourse Analysis. In Bauer, M. W. and Gaskell, G. D. Qualitative Researching with Text, Image and Sound: A Practical Handbook for Social Research, pp. 172-190. Sage: London.

Guerrina, R. (2001) Equality, difference and motherhood: the case for a feminist analysis of equal rights and maternity legislation. Journal of Gender Studies, 10,1, 33-42.

Hagemann-White, C. (1989) Wir werden nicht zweigeschlechtlich geboren. In HagemannWhite, C. and Rerrich, M. S. FrauenMännerBilder, pp. 224-235. AJZ-Verlag: Bielefeld.

Harding, S. (1986) The science question in feminism. Cornell University Press: Ithaca. 
Hare-Mustin, R. T. and Marecek, J. (1994) Gender and the meaning of difference. Postmodernism and psychology. In Herrman, A. C. and Stewart, A. J. Theorizing feminism: parallel trends in the humanities and the social sciences. Westview: San Francisco.

Hartsock, N. (1987) The feminist standpoint: Developing the ground for a specifically feminist historical materialism. In Harding, S. Feminism and Methodology. Open University Press: Milton Keynes.

Hearn, J. (2000) On the complexity of feminist intervention in organizations. Organization, 7,4, 609-624.

Hughes, C. (2002) Key concepts in feminist theory and research. Sage: London.

Jay, N. (1989) Geschlechterdifferenzierung und dichotomes Denken. In Schaeffer-Hegel, B. and Watson-Franke, B. Männer, Mythos, Wissenschaft, pp. 245-262. CentaurusVerlagsgesellschaft: Pfaffenweiler.

Kanter, R. M. (1977) Men and women of the corporation. Basic Books: New York.

Knapp, G.-A. (1998) Gleichheit, Differenz, Dekonstruktion: Vom Nutzen theoretischer Ansätze der Frauen- und Geschlechterforschung für die Praxis. In Krell, G. Chancengleichheit durch Personalpolitik. Gabler: Wiesbaden.

Liff, S. and Cameron, I. (1997) Changing equality cultures to move beyond 'women`s problems'. Gender, Work and Organization, 4,1, 35-46.

Liff, S. and Wajcmann, J. (1996) 'Sameness' and 'difference' revisited: which way forward for equal opportunity initiatives? Journal of Management Studies, 33,1, 79-95.

Lorber, J. (1994) Paradoxes of gender. Yale University Press: New Haven.

Lorber, J. (1996) Beyond the binaries: depolarizing the categories of sex, sexuality and gender. Sociological Inquiry, 66,2, 143-159.

Lorber, J. (1997) The variety of feminisms and their contribution to gender equality. Bibliotheks- und Informationssystem der Universität Oldenburg: Oldenburg.

Lorber, J. (2000) Using gender to undo gender. Feminist Theory, 1, 1, 79-95.

Lorber, J. and Farrell, S. A. (1991) The social construction of gender. Sage: Newbury Park.

Meriläinen, S. (2000) Discourses of equality and difference in bank managers' talk. LTA / The Finnish Journal of Business Economics, 3, 416-432.

Meyerson, D. E. and Kolb, D. M. (2000) Moving out of the 'armchair' : Developing a framework to bridge the gap between feminist theory and practice. Organization, 7,4, 553-571. 
Nentwich, J. C. (2004) Die Gleichzeitigkeit von Differenz und Gleichheit. Konstruktionen von Gleichstellung und Geschlecht in Sprachspielen. Ulrike Helmer Verlag: Königstein i.T.

Oseen, C. (1997) The sexually specific subject and the dilemma of difference. In Prasad, P., Mills, A. J., Elmes, M. and Prasad, A. Managing the organizational melting pot. Dilemmas of workplace diversity, pp.54-79. Sage: Thousand Oaks.

Phillips, A. (1987) Feminism and equality. Blackwell: Oxford.

Potter, J. and Wetherell, M. (1987) Discourse and social psychology. Beyond attitudes and behaviour. Sage: London.

Rao, A., Stuart, R. and Kelleher, D. (1999) Gender at work. Organizational change for equality. Kumarian Press: West Hartford.

Rapoport, R., Bailyn, L., Fletcher, J. K. and Pruitt, B. H. (2002) Beyond work-family balance: Advancing gender equity and workplace performance. Jossey Bass: San Francisco.

Reskin, B. F. and Roos, P. A. (1990) Job queues, gender queues: Explaining women's inroads into male occupations. Temple University Press: Philadelphia.

Riley, S. C. E. (2002) Constructions of equality and discrimination in professional men's talk. British Journal of Social Psychology, 41, 443-461.

Scott, J. (1988) Deconstructing equality-versus-difference: Or, the uses of poststructuralist theory for feminism. Feminist Studies, 14,1, 33-50.

de Shazer, S., Kim Berg, I., Lipchik, E., Nunally, E., Molnar, A., Gingerich, W. and WeinerDavis, M. (2001) Kurzzeittherapie: Zielgerichtete Lösungsentwicklung. In Watzlawick, P. and Nardone, G. Kurzzeittherapie und Wirklichkeit. Eine Einführung, pp. 165-197. Piper: München.

Speer, S. A. (2005) Gender talk. Feminism, discourse and conversation. Routledge: London.

Weatherall, A. (2002) Gender, language and discourse. Routledge: London.

West, C. and Zimmerman, D. H. (1987) Doing Gender. Gender \& Society, 1,2, 125-151.

Wetherell, M. (1998) Positioning and interpretative repertoires: conversation analysis and post-structuralism in dialogue. Discourse \& Society, 9, 387-412.

Wetherell, M., Stiven, H. and Potter, J. (1987) Unequal egalitarianism: A preliminary study of discourses concerning gender and employment opportunities. British Journal of Social Psychology, 26, 59-71.

Wittgenstein, L. (1958). Philosophical Investigations (translated by G. Anscombe, 3rd ed.). New York: Macmillan. 
Witzel, A. (2000, January) The problem-centered interview [27 paragraphs]. Forum: Qualitative Social Research [On-line Journal], 1,1. Online at: http://www.qualitativeresearch.net/fqs-texte/1-00/1-00witzel-e.htm.

Wood, L. A. and Kroger, R. O. (2000) Doing discourse analysis. Methods for studying action in talk and text. Sage: Thousand Oaks.

\footnotetext{
${ }^{1}$ The English notions of 'equal opportunities,' 'gender equity' and 'gender equality' each imply a different theoretical model. The term 'equal opportunities' stands for a structural approach, 'gender equity' is rooted in standpoint feminism and 'gender equality' is the expression used by individual 'promote the women' feminists. However, this is not the case in German. The German word Gleichstellung is used in a more practical sense describing the concrete tasks and objectives of realizing equality legislation, but does not have any implications for the theoretical concepts used. Writing this paper in English, I had to make a decision regarding translating the term in the sense of transferring the original meaning while remaining understandable in an English-speaking context. I therefore decided to use two translations in this paper. I use the term 'gender equality' as a translation of Gleichstellung when referring to the theoretical dilemmas of difference and sameness, but 'equal opportunities' for the concrete tasks necessary to put equality legislation into practice.

${ }^{2}$ The so-called "Gleichstellungsgesetz"

${ }^{3}$ All ten interviews were conducted from July 2001 through February 2002 by the author and were later transcribed and analyzed. The original Swiss-German was translated into English for this paper by the author.

${ }^{4}$ St. Gallen, Graubünden, Appenzell-Innerrhoden and Appenzell-Ausserrhoden

${ }^{5}$ The variety of solutions in companies is also due to the domination of small companies in Eastern Switzerland. These small companies, often family enterprises, have no official equality policy or equal opportunity officers.
} 